LAPORAN KASUS

\title{
Hipoglikemia Berat pada Pasien Syok Sepsis karena Perforasi Gaster
}

\section{Severe Hypoglycemia in Septic Shock Patients Because of Gastric Perforation}

Andre Ferdinand Karema ${ }^{\bowtie}$, Eddy Rahardjo, Pranada Surya Airlangga, Bambang Pujo Semedi

Departemen Anestesiologi dan Terapi intensif, Fakultas Kedokteran Universitas Airlangga/ RSUD Dr. Soetomo Surabaya, Indonesia

${ }^{\square}$ Korespondensi: andrekarema@yahoo.com

\begin{abstract}
Background: Generally, critical patients with septic shock suffer from hyperglycemia. Severe hypoglycemia rarely occurs in critical patients. Based on Bagshaw et al research, severe hypoglycemia occurs in about 1,4\% patients of critical patients population. Severe hypoglycemia caused by fulminant hepatic failure or adrenal failure, septic shock, and severe comorbids (malnutrition, liver cirrhosis, chronic kidney disease). Patients with gastric perforation which are treated in intensive care unit of Dr. Soetomo General Hospital's Emergency Room for one year (2017) was about 11 patients. In this case report there were 3 patients who suffered from hypoglycemia and 2 of them suffered from severe hypoglycemia. Generally, patients with septic shock suffer from hyperglycemia, but there were 3 patients with hypoglycemia and 2 of them were severe hypoglycemia.

Case: Three cases reported as severe hypoglycemia patients who suffered from septic shock because of gastric perforation. All of 3 patients suffered acute kidney injury and hypoalbumin, also got ventilator support.

Discussion: Hypoglycemia should be immediately resolved to prevent unwanted complications. Patients who did not get glucose intake for 2 days should be given an immediate intake. When the hypoglycemia occur, the mortality will increase by $40 \%$ and the severe hypoglycemia will increases to $80 \%$. The most causes of hypoglycemia were acute kidney injury, hypoalbumin, and mechanical ventilation.

Conclusion: If there is critical patients with gastric perforation,laparotomy, acute kidney injury, fasting and uses the mechanical ventilator, should checked the blood sugar levels as early as possible and repeatly. If the patient suffer from hypoglycemia, should be given therapeutic immediately to increase the blood sugar, and should be given adequate glucose intake.
\end{abstract}

Keywords: critical patients; gastric perforation; glucose level test; hypoglycemia; septic shock 


\begin{abstract}
ABSTRAK
Latar Belakang: Secara umum pasien kritis dengan syok septik mengalami hiperglikemia. Hipoglikemia berat sangat jarang terjadi pada pasien kritis. Pada penelitian Bagshaw dkk, hipoglikemia berat terjadi sekitar 1,4\% dari populasi pasien kritis. Hipoglikemia berat disebabkan gagal hati fulminan atau gagal adrenal, syok septik, dan komorbid berat (malnutrisi, sirosis hati, gagal ginjal kronik). Pasien perforasi gaster yang dirawat di ruang intensif emergensi RSUD Dr. Sutomo selama satu tahun (2017) berjumlah 11 pasien. Pada laporan kasus ini 3 pasien mengalami hipoglikemia dimana 2 diantaranya hipoglikemia berat. Pada umumnya pasien kritis dengan syok sepsis mengalami hiperglikemia, namun pada 3 pasien terjadi hipoglikema dan 2 di antaranya hipoglikemia berat .
\end{abstract}

Kasus: Tiga kasus dilaporkan sebagai pasien hipoglikemia berat yang mengalami syok septik disebabkan perforasi gaster. Ketiga pasien dengan mengalami acute kidney injury, hipoalbumin, serta mendapat support ventilator.

Diskusi: Hipoglikemia harus segera diatasi untuk mencegah komplikasi yang tidak diinginkan. Pasien yang tidak mendapat asupan glukose selama 2 hari harus segera diberikan asupan. Bila hipoglikemia terjadi maka mortalitas akan meningkat $40 \%$ dan hipoglikemia berat akan meningkat sampai $80 \%$. Penyebab Hipoglikemia paling banyak antara lain acute kidney injury, hipoalbumin, dan ventilasi mekanik.

Kesimpulan: Apabila dijumpai pasien kritis perforasi gaster, laparatomi, acute kidney injury, puasa dan menggunakan mekanikal ventilator sebaiknya kadar gula darah diperiksa seawal mungkin dan berulang. Apabila pasien mengalami hipoiglikemia, pasien diterapi secepatnya untuk meningkatkan gula darah, serta perlu diberikan asupan glukosa yang memadai.

Kata Kunci: hipoglikemia; pasien kritis; pemeriksaan kadar glukosa; perforasi gaster; syok septik

\title{
PENDAHULUAN
}

Pada umumnya pasien kritis akan mengalami hiperglikemia. Hal ini terjadi karena respons dari sindrom metabolik oleh karena peningkatan pelepasan mediator pro inflamatori dan hormon kontra sehingga terjadi insulin resisten berlebihan. ${ }^{1}$

Hiperglikemia pada pasien kritis akibat respons tubuh terhadap katekolamin, glucagon dan kortisol yang menekan produksi insulin pada saat terjadi glukoneogenesis dan gluconeolisis. ${ }^{1}$

Sedangkan terjadinya hipoglikemia pada pasien kritis sangat jarang terjadi. Hal ini disebabkan karena insulin terapi (iv,Sc), obat anti diabetes, nutrisi enteral maupun parenteral disertai dengan insulin, puasa, operasi besar, diabetes, komorbid berat seperti gagal jantung, gagal hati, gagal ginjal), syok septik, serum kreatinin $\geq$ $3 \mathrm{mg} / \mathrm{dl}$, mekanikal ventilasi, apache score > 25,2, usia (geriatri) dan periode terapi insulin tight glucosecontrol. ${ }^{2-5}$ 


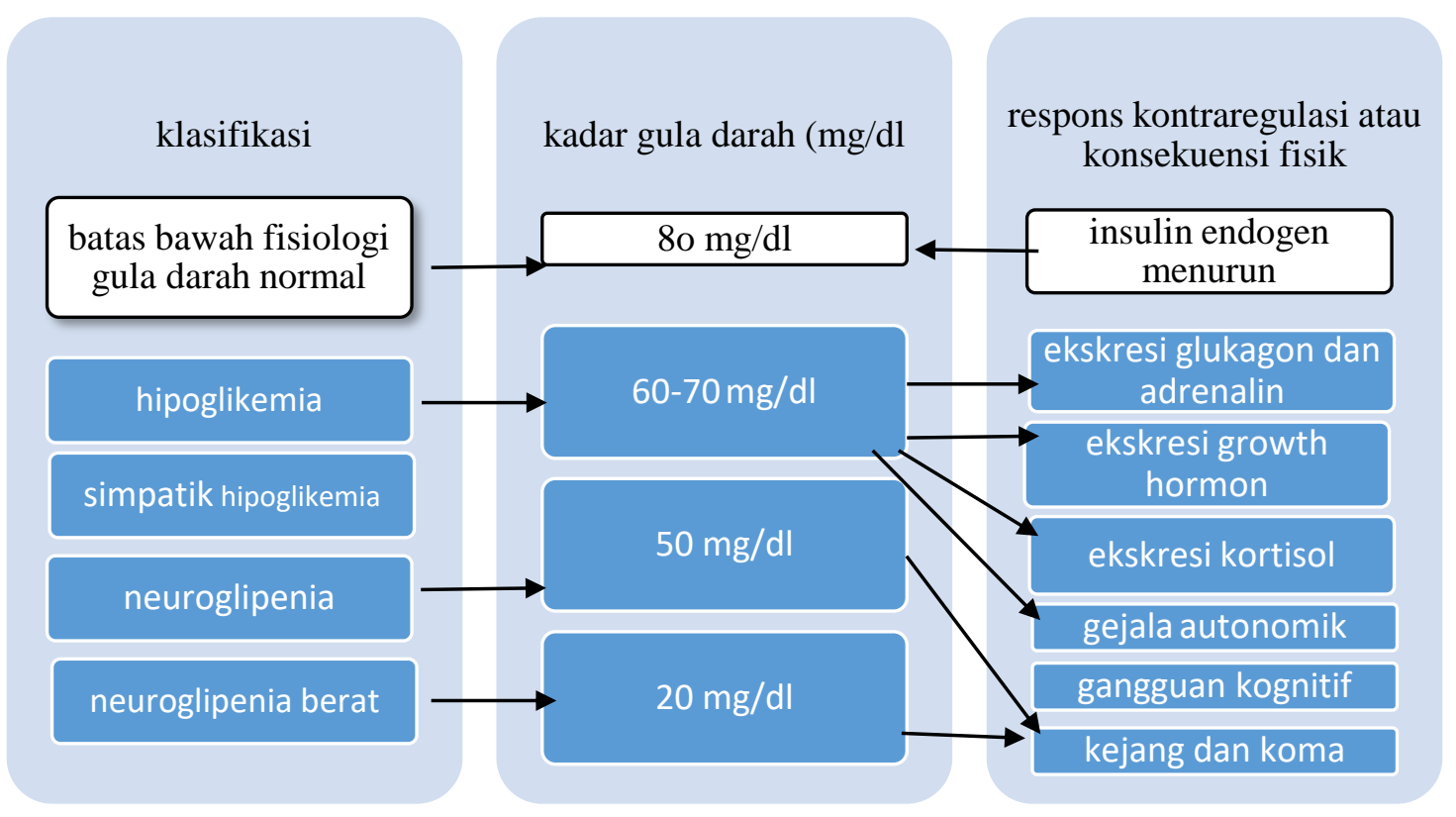

Gambar 1. Skema kadar gula darah dan respons kontraregulasi serta komplikasi pada penggunaan insulin menyebabkan hipoglikemia.

De Galan, et al. Hypoglycaemia and hypoglycaemia unawareness, Ned JM, sept 2006; 6 4 no.8. ${ }^{6}$
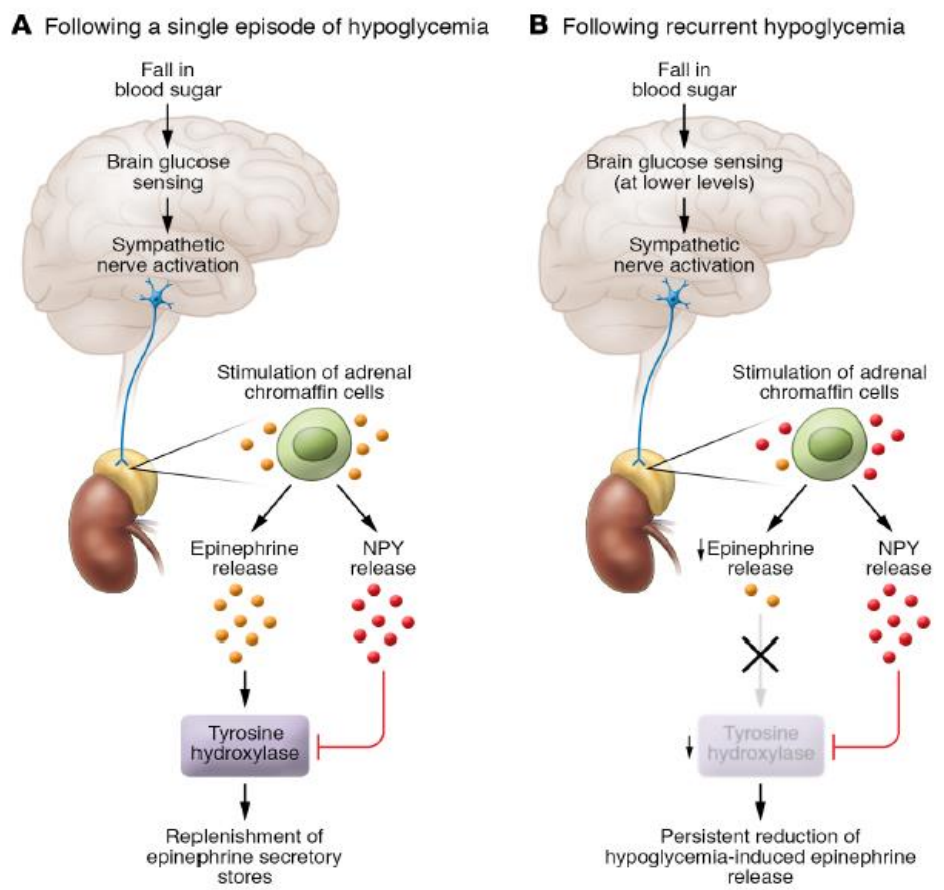

Gambar 2. Inhibisi respons epinefrin pada hipoglikemia yang rekuren (A. Respons awal terjadinya hipoglikemia, B. Respons hipoglikemia berulang)

Seaquist ER, Beyond the brain: do peripheral mechanisms develop impaired awareness of hypoglycemia?, J Clin Invest. 2018;128(9):3739-3741. ${ }^{7}$ 


\section{KASUS}

Terdapat 3 kasus yang dilaporkan sebagai hipoglikemia berat yang dirawat di ruang intensif emergensi RSUD Dr. Sutomo dengan underlying disesase pascaoperasi perforasi gaster.

\section{Kasus 1}

Seorang wanita 60 tahun dengan berat badan 55kg (BMI 23,43) masuk Instalasi Rawat Darurat (IRD) dengan keluhan sesak dan mengantuk, riwayat nyeri perut 10 hari memberat 2 hari dan muntah 2 hari. Diagnosa syok septik dengan perforasi gaster dilakukan resusitasi dan pemberian vasopresor pasien direncanakan operasi. Pemeriksaan penunjang yang bermakna $\mathrm{Hb}$ 6,6 gr/dl, leukosit 23.000 per $\mu \mathrm{L}$, trombosit 654.000 per $\mu \mathrm{L}$, hipoalbumin 2,21 , laktat 4,1, procalcitonin 184,66 dan kreatinin serum meningkat 3,67 $\mathrm{mg} / \mathrm{dL}$. Dilakukan operasi laparatomi eksplorasi, ditemukan perforasi gaster dan dilakukan repair. Pasien masuk ke perawatan intensif dengan diagnosa gagal napas, syok septik, acute kidney Injury, anemia, hipoalbuminemia.

Pada perawatan hari kedua terjadi penurunan kesadaran, kadar gula darah pertama $15 \mathrm{mg} / \mathrm{dL}$ mendapat resusitasi dekstrose $40 \% \quad 50 \mathrm{~mL}$ gula darah meningkat menjadi $22 \mathrm{mg} / \mathrm{dL}$. Pemberian dekstrose $40 \% 50 \mathrm{~mL}$ yang kedua meningkatkan gula darah 34 $\mathrm{mg} / \mathrm{dL}$. Dilakukan pengulangan kembali dekstrose $40 \% 50 \mathrm{~mL}$, gula darah menjadi 94 mg/dL. Hari ke-3 gula darah $117 \mathrm{mg} / \mathrm{dL}$ tanpa pemberian dekstrose $40 \%$ ulangan. Setelah 8 hari perawatan pasien masih dengan supporty ventilator dan vasopressor. Pasien diminta pulang paksa oleh keluarganya tanpa alasan yang jelas.

\section{Kasus 2}

Laki-laki 63 tahun dengan berat badan $60 \mathrm{~kg}$ (BMI 23,43) masuk IRD dengan sesak, ada riwayat muntah dan nyeri perut 2 hari yang lalu. Pasien di diagnosa dengan perforasi gaster dengan syok sepsis, dilakukan resusitasi cairan dan vasopresor sesuai sepsis bundle Pemeriksaan penunjang di dapatkan $\mathrm{Hb}$ 12,5, leuko 5500 per $\mu \mathrm{L}, \mathrm{Na} 139, \mathrm{~K} 4,9$, Cl 11, Albumin 2,2, Sc 1,82 dan laktat 2,3. Dilakukan operasi laparatomi eksplorasi repair perforasi gaster.

Pasien masuk ke ruang perawatan intensif emergency RSUD Dr. Sutomo setelah operasi dengan diagnosa syok sepsis, acute kidney injury (AKI), hipoalbumin. Pada perawatan hari pertama, terjadi penurunan kesadaran, kadar gula darah pertama $34 \mathrm{mg} / \mathrm{dL}$ mendapat dekstrose $40 \% 50 \mathrm{~mL}$ gula darah meningkat menjadi $177 \mathrm{mg} / \mathrm{dL}$. Setelah 3 jam gula darah turun lagi 63 $\mathrm{mg} / \mathrm{dL}$ mendapat ulangan dekstrose $40 \%$ $50 \mathrm{~mL}$ menjadi $94 \mathrm{mg} / \mathrm{dL}$. Setelah itu gula darah tidak menurun tanpa pemberian dekstrose $40 \%$ ulangan.

Pasien selama 3 hari dirawat di ruang high care unit (HCU) dalam kondisi baik. Pada hari ke-6 perawatan ruangan pasien mengalami sesak yang tidak teratasi dan meninggal.

\section{Kasus 3}

Seorang wanita 68 tahun dengan berat badan $43 \mathrm{~kg}$ (BMI $20 \mathrm{~kg} / \mathrm{m}^{2}$ ) masuk IRD dengan sesak dan penurunan kesadaran. Riwayat nyeri perut 3 hari yang lalu dan muntah 3 hari yang lalu. Dari rumah sakit sebelumnya pasien pemeriksaan gula darah $84 \mathrm{mg} / \mathrm{dL}$. Saat dalam pemeriksaan lab RSUD Dr. sutomo gula darah pertama $24 \mathrm{mg} / \mathrm{dL}$ mendapatkan dekstrose $40 \% 50 \mathrm{~mL}$ menjadi 230 $\mathrm{mg} / \mathrm{dl}$. 
Pasien di diagnosa dengan syok sepsis ec perforasi organ berongga, acute kidney injury, anemia, hipoalbuminemia, pascahipoglikemia berat. Pemeriksaan penunjang $\mathrm{Hb} 8,6$, leukosit dalam batas normal, Na 136, K 3,6, Cl 101, Sc 3,28, Albumin serum 2,82, APTT $>1,5 \mathrm{x}$ dari kontrol, asidosis metabolik. Dilakukan resusitasi cairan sesuai sepsis bundle, dilakukan eksplorasi laparatomi repair perforasi gaster. Selama operasi pasien mendapat vasopresor dan support ventilator.

Perawatan hari pertama pemeriksaan gula darah turun menjadi $54 \mathrm{mg} / \mathrm{dL}$ mendapatkan dekstrose $40 \% \quad 50 \mathrm{~mL}$ ulangan gula darah menjadi $107 \mathrm{mg} / \mathrm{dL}$. Setelah itu gula darah tidak menurun tanpa pemberian dekstrose $40 \%$ ulangan.

Pasien tidak membaik selama 12 hari perawatan dengan support ventilator, pasien pernah dilakukan penyapihan 2 kali namun gagal, pasien masih dalam kondisi syok dengan bantuan vasopressor dan pasien mengalami artrial fibriasi. Keluarga pasien menolak perawatan dan pulang paksa tanpa alasan yang jelas.

\section{PEMBAHASAN}

Kasus hipoglikemia jarang terjadi pada pasien kritis. Penyebab hipoglikemia adalah puasa, insulin terapi, nutrisi disertai insulin terapi, diabetes, komorbid berat (gagal jantung, gagal hepar, gagal ginjal), syokseptik, serum kreatinin $\geq 3 \mathrm{mg} / \mathrm{dl}$, laparatomi, ventilasi mekanik, apache $>25,2$, geriatri, dan terapi tight glucose control. ${ }^{2-6}$ Kesulitan diagnosa hipoglikemia dan penanganan yang tertunda menyebabkan pasien jatuh ke keadaan hipoglikemia maupun hipoglikemia berat menyebabkan meningkatkan mortalitas tinggi. Nice sugar investigation (2012) mendapatkan pasien hipoglikemia mortalitas meningkat $40 \%$ sedangkan hipoglikemia berat meningkat sampai dengan $80 \%{ }^{3,8}$

Pasien pertama yang selama 4 hari tidak mendapatkan glukosa, mengalami hipoglikemia berat berulang sampai dengan 3 kali. Gula darah pertama 15 $\mathrm{mg} / \mathrm{dL}$ mendapat dekstrose $40 \% 50 \mathrm{~mL}$ menjadi $22 \mathrm{mg} / \mathrm{dL}$. Terapi dekstrose $40 \% 50 \mathrm{~mL}$ ulangan yang kedua meningkatkan gula darah $34 \mathrm{mg} / \mathrm{dL}$. Setelah dekstrose $40 \% 50 \mathrm{~mL}$ ulangan gula darah menjadi $94 \mathrm{mg} / \mathrm{dL}$.

Pasien ke-2 selama 3 hari tidak mendapatkan glukosa dan mengalami hipoglikemia berat. Gula darah pertama $34 \mathrm{mg} / \mathrm{dL}$ mendapat dekstrose $40 \%$ $50 \mathrm{~mL}$ menjadi $177 \mathrm{mg} / \mathrm{dL}$. Setelah 3 jam gula darah $63 \mathrm{mg} / \mathrm{dL}$ mendapat dekstrose $40 \%$ 50mL ulangan menjadi $94 \mathrm{mg} / \mathrm{dL}$.

Pasien ke-3 selama 3 hari tidak mendapatkan glukosa mengalami hipoglikemia berat. Gula darah pertama $24 \mathrm{mg} / \mathrm{dL}$ mendapatkan dekstrose $40 \%$ $50 \mathrm{~mL}$ menjadi $230 \mathrm{mg} / \mathrm{dl}$, setelah satu hari gula darah turun menjadi $50 \mathrm{mg} / \mathrm{dL}$ mendapatkan dekstrose $40 \% 50 \mathrm{~mL}$ lagi gula darah menjadi $107 \mathrm{mg} / \mathrm{dL}$. Pada penelitian Hierberg B, et all (2000) penelitian sampel sebanyak 127 pasien.

Pasien hipoglikemia disertai dengan tanda dan gejala terjadi setelah 12 jam puasa adalah $43 \%$ pasien, 24 jam puasa $67 \%$ pasien dan 48 jam puasa $95 \%$ serta 72 jam puasa menjadi $100 \% .{ }^{9,10}$ Pada ketiga pasien puasa lebih dari 72 jam dan dipastikan hipoglikemia berat berulang setelah pemberian dekstrose $40 \%$ 50mL. ${ }^{9}$ Pada penelitian NICE-SUGAR evaluasi 60245 pasien kritis :2714(45\%) hipoglikemia sedang, 2237 (82,4\%) grup kontrol intensif insulin dan $223(3,7 \%)$ hipoglikemia berat, 208 (93\%) grup kontrol intensif insulin. 
Ratio kematian antara hipoglikemia sedang dan berat dibandingkan dengan yang tidak hipoglikemia, 1,41 (95\% confidence interval [CI] 1,21 - 1,62 $\mathrm{P}<0,001$ dan 2,10 (95\% CI, 1,59$2,77 ; \mathrm{P}<0,001)$. Kematian pada pasien hipoglikemia berat yang tidak menggunakan insulin (hazard ratio,3.84;95\%CI,2,37-6,23;P<0,001). ${ }^{3}$

Pasien kritis dan syok sepsis terjadi hipoglikemia berhubungan dengan prognosis jelek tanpa identifikasi yang jelas dari penyebab mortalitas yang tinggi. ${ }^{3,4,8}$ Hipoglikemia berat meningkatkan mortalitas dan dapat berhubungan dengan penyakit penyerta yang berat. $3,4,10$

57 pasien dari 102 pasien dengan hipoglikemia berat meninggal $(55,9 \%)$ dibanding 121 dari 306 kasus kontrol $(39,5 \%) \mathrm{p}=0,0057$ (chisquare test). Jadi mortalitas kohort 5263 pasien dengan hipoglikemia berat adalah $16,3 \%{ }^{8}$ Hal ini dicurigai karena habisnya produksi glukosa endogen dan menunjukan penyakit kritis yang dialami pasien.

Diagnosis hipoglikemia pada pasien kritis menjadi tantangan. Pemeriksaan rutin glukosa bedside sering kali tidak dapat mendeteksi hipoglikemia pada kisaran rendah, dan tanda neurologik hipoglikemia dapat disamarkan. ${ }^{2,11,12}$

Ketiga pasien didapatkan kreatinin serum meningkat. Pasien pertama serum kreatinin 3,67 mg/dL, pasien ke-2 serum kreatinin $1,82 \mathrm{mg} / \mathrm{dL}$, dan pasien ke-3 serum kreatinin 3,28 $\mathrm{mg} / \mathrm{dL}$. kadar serum kreatinin plasma meningkat bisa di sebabkan acute kidney injury yang disebabkan oleh syok sepsis, hal ini yang merupakan faktor penyebab hipoglikemia. ${ }^{8} \quad$ Pasien belum terdiagnosis adrenal insufisiensi karena kurang ketersediaan fasilitas.

Pemberian ACTH untuk deteksi respons hormon kortisol dalam darah. Bila kadar kortisol dalam darah rendah setelah pemberian ACTH pasti terjadi adrenal insufisiensi. Ada literatur pasien adrenal insufisiensi bila mendapatkan tanda hipoglikemia dan syok refrakter dapat diberikan kortisol $50 \mathrm{mg}$ tiap 6 jam sampai dapat di buktikan dari penyebab lain. ${ }^{13}$

Pasien pertama dan ketiga support ventilation yang lama berhubungan dengan kadar serum kreatinin diatas 3 dan juga kedua pasien juga mendapat support vasokonstriktor lama. ${ }^{8}$ Pada literatur ada hubungan antara kadar serum kreatinin dengan mechanical ventilation, bila kadar serum kreatinin > $3 \mathrm{mg} / \mathrm{dl}$ pasien lebih lama untuk penyapihan ventilator. ${ }^{8}$

Ketiga pasien mengalami hipoalbuminemia, menandakan proses katabolisme yang besar. Hal ini dapat disebabkan oleh syok sepsis, kurangnya intake makanan, malnutrisi dan peningkatan kadar serum kreatinin, ventilasi mekanik. Kurangnya intake makanan dan kataboluisme yang besar menyebabkan hipoglikemia pada ketiga pasien. $^{12}$

Hipoglikemia juga dapat disebabkan oleh respons kortisol yang dipicu oleh stres endogen. Biasanya hipoglikemia berat, kadar kortisol diatas $25 \mathrm{mcg} / \mathrm{dl}$. Pada septik syok dan operasi laparatomi menghasilkan respons stres yang berat sehingga kadar kortisol akan lebih tinggi dan memungkinkan terjadi hipoglikemia berat. ${ }^{13,14}$. 
Pemeriksaan kadar glukosa darah harus rutin dilakukan terutama pasien kritis dengan syok septik, seharusnya dilakukan sebelum hari ke-20 setelah adanya gejala nyeri perut dan muntah.

Pada pasien pertama pemeriksaan gula darah setelah 4 hari pasien tidak mendapatkan asupan glukosa dan deteksi gula darah terlambat 1 hari setelah perawatan intensif.

Pada pasien ketiga menunjukkan gula darah mulai menurun pada hari kedua dan puncak hipoglikemia terjadi pada hari ketiga. Semua pasien gula darah dibawah $30 \mathrm{mg} / \mathrm{dl}$.

Pada pasien pertama dan ke-2 sudah berada di ruang intensif dan gejala hipoglikemia tersamarkan dengan pemberian obat sedasi dan syok sepsis. ${ }^{14}$

Terapi Hipoglikemia dilakukan dengan pemberian preparat Dektrose $40 \% 25$ $\mathrm{mL}(10 \mathrm{mg} / \mathrm{mL})$ IV dengan asumsi meningkatkan gula darah $25 \mathrm{mg} / \mathrm{dL}$, tetapi pada kenyataan pasien pertama mengalami hipoglikemia refrakter. Pasien sudah diberikan Dekstrose $40 \%$ $50 \mathrm{~mL}$ dan dikontrol cairan yang mengandung dextrose $5 \% .^{15}$

Penyebab hipoglikemia berat refrakter pada pasien ini adalah: puasa, malnutrisi, insufisiensi adrenal, laparatomi dan syok septik. Pasien di berikan dekstrose, kadar glukosa darah meningkat tidak seperti yang diharapkan. Pemilihan pemberian alternatif glukagon dan epinefrin untuk meningkatkan glukoneogenesis dan glikoneolisis tidak dilakukan pada pasien ini.

Pada hipoglikemia refrakter patut dicurigai insufisiensi adrenal pemberian Dektrose $40 \%$ harus ditambahkan kortikosteroid (kortison). Kekurangan dalam kasus ini kadar kortisol tidak di periksakan karena kurang fasilitas untuk mengetahui adanya adrenal insufisiensi. Bila perlu kortisol dapat di berikan 50 mg IV tiap 6 jam. ${ }^{15,16}$

Pada pasien ketiga selama dalam perawatan pasien mengalami atrial fibrilasi. Pada literatur pasien dengan hipoglikemia sedang dan berat dapat terjadi aritmia. ${ }^{3}$ Pada pasien pertama dan kedua tidak dijumpai aritmia.

\section{KESIMPULAN}

Apabila dijumpai pasien kritis perforasi gaster, laparatomi, acute kidney injury, puasa dan menggunakan ventilasi mekanik, sebaiknya kadar gula darah diperiksa seawal mungkin dan berulang. Apabila pasien mengalami hipoglikemia, pasien diterapi secepatnya dan untuk meningkatkan gula darah serta perlu diberikan asupan glukosa yang memadai. Hipoglikemia meningkatkan mortalitas pasien kritis. Bila terjadi hipoglikemia berulang, pertimbangkan pemberian kortisol $50 \mathrm{mg}$ tiap 6 jam intravena.

\section{DAFTAR PUSTAKA}

1. Arik PE, Raghavan M .Stresshyperglycemia insulin and immunomodulation in sepsis. In: Applied Physiology in intensive care medicine 2, Spinger 2012, 153-61

2. Lacherade JC, Jacqueminet $S$, Preiser JC. An Overview of hypoglycemia in critically ill. $\mathrm{J}$ diabetes Sci tech, vol3, issue 6. Nov 2009:1252-8

3. Finter S, Liu B, Chittock DR, et all. Hypoglycemia and risk of death in critically ill patients, the NICESUGAR. N Eng J Med 2012;367:1108-18

4. Kalton P. Manach YL, Ichai C, et all. Severe and multiple hypoglycemia 
episodes are associated with increased risk of death in ICU patients. Critical care 2015; 19: 153.

5. Hulkower RD, et all. Understanding hypoglycemia in hospitalized patients. Diabetes manage 2014;4(2): 160-76

6. De Galan, et al. Hypoglycaemia and hypoglycaemia unawareness, Ned JM, sept 2006; 64 no.8

7. Seaquist ER, Beyond the brain: do peripheral mechanisms develop impaired awareness of hypoglycemia?,J Clin Invest. 2018;128(9):3739-3741

8. Krinsley JS, Grover A, Severe hypoglycemia in crittically ill patients: risk and outcomes. Crit Care Med.2007;35(10): 2262-7

9. Hirsberg B, et all. Fourty eight hour fast: the diagnostic test for insulinoma. J Clin Endoc \& Metab.2000;85:3222-6

10. Bagshaw SM, et all. The impact of early hypoglycemia and blood glucose variability on outcome in critical illness. Critical care. 2009;13:R91

11. Carmody D, Philipson L. Hyperglycemic Crisis and Hypoglycemia. In: Pinciples of critical care $4^{\text {th }}$, McGratHill;2015,987-9

12. Kagansky M, et all. Hypoglycemia as a predictor of mortality in hospitalized elderly patients. Arc Int Med ;11 aug,2003,1825-9

13. Khadori R, Danielle C, Endocrine and Metabolic changesDuring Sepsis : an Update, Med Clin N Am. 2012;96,1095-105

14. Marik PE, Zaloga GP. Adrenal insufficiency in critically ill, a new look at an old problem. Chest, Nov 2002;122(5):1784-96

15. Moore C, Woolard M. Dextrose $10 \%$ or $50 \%$ in treatment of hypoglycemia out of hospital, a randomized control trial. Emerg Med J. 2002; 22: 512-5

16. Cooper MS, Steward PM. Corticosteroid insufficiency in acutely ill patients. NEJM. 2003: 727-34 